\title{
Staphylococcus Derived from Desert and Its Solidified Ability on Aeolian Sandy Soil
}

\author{
Yu Gao $\left(\mathbb{D},{ }^{1,2}\right.$ De Yao $\left(\mathbb{D},{ }^{1}\right.$ Cuiyan Wang $\mathbb{D},{ }^{1}$ Yanxing Wang $(\mathbb{D})^{2}$ and Chi Li $\mathbb{D}^{2,3}$ \\ ${ }^{1}$ College of Chemical Engineering, Inner Mongolia University of Technology, Hohhot 010051, China \\ ${ }^{2}$ College of Civil Engineering, Inner Mongolia University of Technology, Hohhot 010051, China \\ ${ }^{3}$ Key Laboratory of Civil Engineering Structure and Mechanics, Inner Mongolia University of Technology, Hohhot 010051, China
}

Correspondence should be addressed to Chi Li; nmggydxlch@163.com

Received 3 August 2020; Revised 13 September 2020; Accepted 28 September 2020; Published 28 October 2020

Academic Editor: Qiang Tang

Copyright (c) $2020 \mathrm{Yu}$ Gao et al. This is an open access article distributed under the Creative Commons Attribution License, which permits unrestricted use, distribution, and reproduction in any medium, provided the original work is properly cited.

\begin{abstract}
Many soil microorganisms in nature induce carbonate precipitation, which is used in soil improvement to reduce the pollution of soil environment by traditional chemical improvement. With the goal of expanding the geotechnical applications of biomineralizing bacteria, this study investigated the characteristics of a newly identified strain of soil bacteria, including its mineralization ability, its effect on Aeolian sandy soil, and biomineralization crust effect in the desert field test. The autogenous mineralized strain was isolated and purified from desert Aeolian sandy soil, and the strain was identified as Staphylococcus using 16SrRNA sequence homology. It is a kind of mineralized bacteria seldom used in geotechnical engineering at present, and it was found to have good mineralization ability; the living conditions of Staphylococcus were optimized. Under the determined amount of bacteria liquid, the amount of calcium carbonate precipitation after the bacteria liquid reacted with different volumes of calcium source solution was studied to determine the appropriate ratio of bacteria liquid and calcium source solution and the molar amount of calcium source solution. This study also investigated the effect of mineralization on the strength of sand and determined the particle size range of sand and suitable bacteria concentration that Staphylococcus can effectively stabilize. Field test results verified desert autogenous Staphylococcus had a good mineralization effect on sand. It was suitable for Aeolian sandy soil crust and improvement. In this paper, the autogenous strain was applied to the surface of the desert for the first time to form an in situ microbial mineralization crust. The research results can provide a theoretical basis for the better application of autogenous strain in the desert.
\end{abstract}

\section{Introduction}

Microbial mineralization is a common phenomenon in nature and it has attracted great attention in the field of civil engineering [1]. Microorganism remediation technology, widely applied in civil and geotechnical engineering, combines traditional microbial engineering and civil environmental engineering to control or improve water and soil pollutants, thereby protecting the environment. This is another breakthrough in soil improvement.

Microorganisms play an important role in mineralization and precipitation and the porous media was repaired and improved by microbial precipitation [2-4]. Biomineralization is a promising and environmentally friendly technology for improving soil properties [5].
Microorganisms isolated from rich organic matter in nature are often able to carry out metabolic processes such as denitrification, iron reduction, and urease hydrolysis. Cunningham et al. [6] used Pseudomonas aeruginosa to reduce the permeability and porosity of sandy soil. Ranalli et al. [7] from Molise University studied Pseudomonas aeruginosa and Pseudomonas stutzeri to understand their abilities to remove nitrate stains on stone surfaces. Pseudomonas aeruginosa and Staphylococcus aureus during cocultivations and polymicrobial infections were analyzed [8]. In general, urease microorganisms can rapidly induce the crystallization of large amounts of calcium carbonate. This cementing process improves soil strength and stiffness and reduces soil permeability by precipitating calcium carbonate between soil particles or on the surface of soil particles 
[9-11]. Pseudomonas denitrificans has been used to induce calcium carbonate precipitation in granular soil to improve soil properties [12]. Researchers have used denitrifying soil bacteria with calcium acetate and calcium nitrate to stabilize soil $[13,14]$. Biomineralization is a promising and environmentally friendly technology for improving soil properties [5]. Biomediated soil improvement involves the usage of microbes to improve soil engineering performance through a series of biogeochemical processes. A ubiquitous biogeochemical process occurs in soil and results in permanent inorganic cementation between soil grains [15]. Biomediated methods, microbial-induced carbonate precipitation (MICP), and enzymatic-induced carbonate precipitation (EICP) were investigated and compared for their effectiveness in mitigating sand dune erosion under wave attack by model test, and calcite settled on the surface of shallow sand [16].

A urease bacterial strain was isolated from sandy soil by researchers at the Nan yang Technological Institute. These bacteria produced calcium carbonate in the sand, reducing the permeability and improving the strength of the sand. A calcium alginate polymer sealant produced by microorganisms was able to control the seepage of porous materials [17-19]. Twelve urease bacterial strains are isolated from two kinds of soil by Hammes [20] and Dick [21], including Bacillus sphaericus and Bacillus lentus, were shown to effectively treat concrete and calcareous wastewater, forming a calcium carbonate layer on the limestone surface to repair degraded limestone [22]. A team of researchers used phosphate-mineralizing bacteria to induce barium phosphate precipitation and cement sandstone, varying the $\mathrm{pH}$ of this process produced different sandstone morphologies $[23,24]$. Urease microorganisms can produce carbonate and ammonium ions and crystallize calcium carbonate, improving the engineering properties of soil and stabilizing sand $[2,3,25,26]$.

Microbial-induced carbonate precipitation (MICP) technology can reinforce and improve the strength of soil, with applications in biological plugging, biological cementation, and fracture repair [27]. Mutant strains with high urease levels have been used to reinforce liquefied foundations [28-31]. The cementing ability of Sporosarcina pasteurii has been studied in gravel. By controlling the grouting speed, grouting time, and the amount of bacteria and cementing liquid, this method improved the strength of sandy soil and controlled the infiltration of sandy soil, producing a uniaxial compressive strength of $1100 \mathrm{~m}^{3}$ after cementing [28]. Researchers at the University of California studied soil improvement and slope reinforcement by Sporosarcina pasteurii, and mineralization of Aeolian sandy soil produced an unconfined compressive strength (UCS) of $0.66 \mathrm{MPa}[9,30,32]$. MICP technology was also used to carry out bonding experiments and strength characteristic tests [33-35]. In both laboratory and field experiments using MICP, Sporosarcina pasteurii (ATCC 11859) was able to mineralize and cement coarse-grained soil $[1,33,36,37]$.

Although good research results have been achieved in the above studies, many laboratory experiments have also been done on the improvement of Aeolian sandy soil by Sporosarcina pasteurii. However, the mineralization of desert soil needs green and pollution-free microbial treatment method, which is easy to be popularized in desert treatment. Our research group has devoted many years to understanding the reinforcement and erosion control of desert Aeolian sandy soil [38-41]. Microbial mineralization technology was gradually introduced into desert improvement. A number of laboratory experiments have demonstrated the feasibility of using Sporosarcina pasteurii to solidify Aeolian sandy soil [33-35, 42]. Mineralization enhances the occlusal force of loose sandy soil that otherwise lacks cohesion, forming a stable microbial crust that resists environmental erosion [34]. Autogenous microbial strains prevent contamination of desert soil by foreign microorganisms and biological pollution of the desert. The microbial strain used in the current research is uniquely suited for this purpose. In this research, using selective enrichment culture and plate separation, an autogenous strain was isolated and purified from desert Aeolian sandy soil. The mineralization of sand by this strain was studied and the appropriate particle size range of the sand was determined. Through quantitative analysis of calcium carbonate produced by bacteria with different calcium source concentrations, the most suitable calcium source concentration and the optimal ratio of bacteria solution to calcium source solution were determined. Moreover, the effect of different bacteria concentrations on the strength of sand soil was analyzed. As Desert soil is a good carrier for microorganisms, the mineralization technique was applied to the field mineralization experiment in the desert, the calcium carbonate crust was induced by the isolated mineralization strain, and the stability of the crust was evaluated, which enables floating dune to be semifixed and fixed, hinders wind erosion, and fundamentally blocks the source of sandstorm. This method not only overcomes soil pollution by foreign bacteria, but also improves the effectiveness of mineralization, and provides a theoretical basis for future popularization into using autogenous bacteria in desert soil solidification and crust technology.

\section{Materials and Methods}

2.1. Materials. Sand was divided into eight groups based on the particle size, as shown in Figure 1, and the particle size ranges of different grain groups are shown in Table 1. Standard silica sand served as a control group (CG1) in the experiments. CG1 particle size was less than $5 \mathrm{~mm}$ $(0.075 \sim 5 \mathrm{~mm})$, with most particles between 0.25 and $0.5 \mathrm{~mm}$ and a median particle size of $0.7 \mathrm{~mm}$; the natural bulk density of CG1 was $1.578 \mathrm{~g} / \mathrm{cm}^{3}$ and the soil particle density was $2.63 \mathrm{~g} / \mathrm{cm}^{3}$. The coefficient of uniformity $(\mathrm{Cu})$ of $\mathrm{CG} 1$ was 4.96 , and its coefficient of curvature (Cc) was 1.529. The CG2 sample was taken from the Ulan Buh Desert in the Inner Mongolia Autonomous Region of China. The shallow layer of the desert is rich in water resources, the underground water level is buried $5 \sim 8 \mathrm{~m}$ deep, there are many flowing and semifixed dunes, and the landform is complex. Sand particles in the size range of 0.1 to $0.25 \mathrm{~mm}$ accounted for $85.3 \%$ of the total mass. This sample had fine particles with no cohesive force between grains and it was classified as 


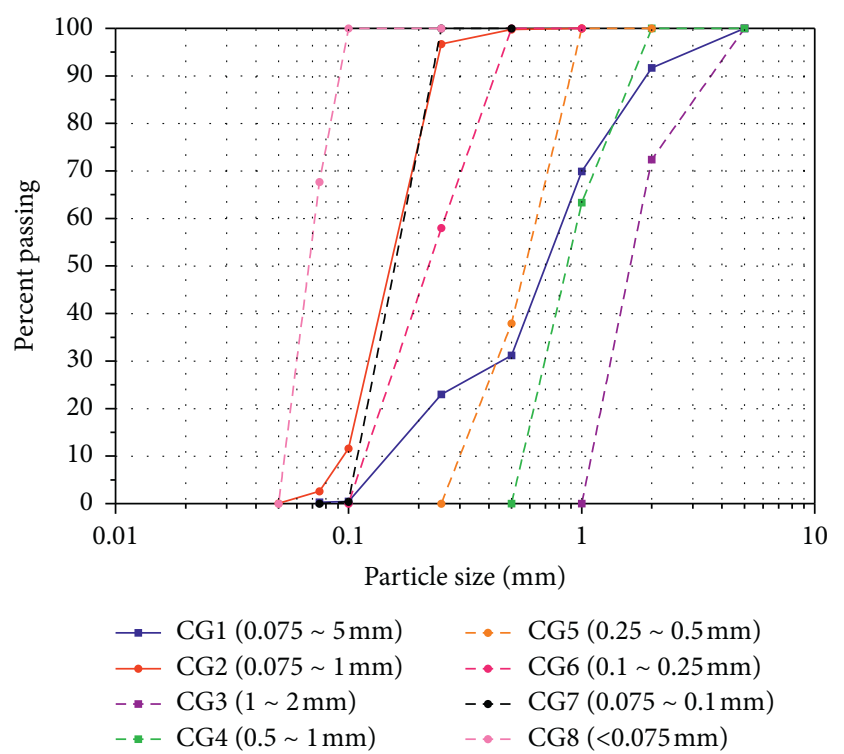

Figure 1: Grain composition curve of different control groups.

Aeolian sandy soil. The natural moisture content was $4.3 \%$, the natural bulk density was $1.615 \mathrm{~g} / \mathrm{cm}^{3}$, and the soil particle density was $2.64 \mathrm{~g} / \mathrm{cm}^{3}$. The inhomogeneity coefficient for CG2 was 1.78, and the Cc was 1.05. Six different grain group of CG3 CG8 were made of standard sand (CG1) by sieving.

2.2. Isolating the Autogenous Bacteria. A sample of desert Aeolian sandy soil was placed in $100 \mathrm{~mL}$ of the liquid medium at low speed in a shaking box for $30 \mathrm{~min}$ to disperse any microorganisms present in the soil, then was allowed to stand for $24 \mathrm{~h}$. Tests were run in triplicate and the average values of samples were used to minimize experimental error. The liquid medium used for the separation, enrichment, and purification of bacteria from Aeolian soil was composed of yeast powder $(15 \mathrm{~g} / \mathrm{L}), \mathrm{CH}_{3} \mathrm{COONa}(0.05 \mathrm{~mol} / \mathrm{L}), \mathrm{NH}_{4} \mathrm{Cl}$ $(0.05 \mathrm{~mol} / \mathrm{L})$, and $\mathrm{CO}\left(\mathrm{NH}_{2}\right)_{2}(0.1 \mathrm{~mol} / \mathrm{L})$. The solid media was composed of yeast powder $(15 \mathrm{~g} / \mathrm{L}), \mathrm{CH}_{3} \mathrm{COONa}$ $(0.05 \mathrm{~mol} / \mathrm{L}), \mathrm{NH}_{4} \mathrm{Cl}(0.05 \mathrm{~mol} / \mathrm{L}), \mathrm{CO}\left(\mathrm{NH}_{2}\right)_{2} \quad(0.1 \mathrm{~mol} / \mathrm{L})$, and agar powder $(20 \mathrm{~g} / \mathrm{L})$.

Next, $1 \mathrm{~mL}$ of supernatant was inoculated to $100 \mathrm{~mL}$ of fresh liquid medium (Figure 2(b)), and this was incubated at $30^{\circ} \mathrm{C}$ for $48 \mathrm{~h}$ with $200 \mathrm{r} / \mathrm{min}$ shaking (Figure 2)(b). A $1 \mathrm{~mL}$ bacteria solution was added to $9 \mathrm{ml}$ liquid medium and shaken for $1 \mathrm{~min}$, then further in turn diluted $\left(10^{-1}, 10^{-2}\right.$, $10^{-3}, 10^{-4}, 10^{-5}$, and $\left.10^{-6}\right)$ in a fresh liquid medium. Bacteria liquid at $10^{-4}, 10^{-5}$, and $10^{-6}$ dilutions were plated on aseptic plates and incubated at $30^{\circ} \mathrm{C}$ for $3-5 \mathrm{~d}$ to isolate single colonies (Figure 2(c)). Single colonies were streaked on plates three times as shown in Figure 2(d). Bacterial screening and extraction were done based on references Zhang et al. [43].

Most of the mineralized strains producing urease can change the initial $\mathrm{pH}$ value of the original medium after shaking culture, which is alkaline [44]. After $24 \mathrm{~h}$ of incubation of a single strain, the $\mathrm{pH}$ was tested by $\mathrm{pH}$ meter. A $1 \mathrm{~mL}$ bacteria solution was added to the acid- base indicator to verify the acid-base change (Figure 2(e)).

In the mineralization reaction between the bacteria solution and the calcium source solution, the volume ratio of bacteria liquid and calcium source solution is also an important factor, which can directly reflect the precipitation amount of calcium carbonate, meanwhile, in order to prevent the excessive nutrient solution from being completely used by bacteria and causing unnecessary waste. Under the determined amount of bacteria liquid, the amount of calcium carbonate precipitation after the bacteria liquid reacted with different volumes of calcium source solution was studied to determine the appropriate ratio of bacteria liquid and calcium source, and the molar amount of calcium source solution.

(1) In order to ensure higher bacteria activity, the bacteria liquid was oscillated for about $18 \mathrm{~h}$, and the $\mathrm{OD}_{600}$ of the bacterial liquid at the peak of the logarithmic growth period was about 1.2 1.4. (2) The calcium source solution was mainly composed of urea and calcium chloride. The molar ratio of urea to calcium ion in the nutrient solution of calcium source is always $1: 1$. Six different calcium sources solution with a molar of $0.5 \mathrm{M}, 1.0 \mathrm{M}, 1.5 \mathrm{M}, 2.0 \mathrm{M}, 2.5 \mathrm{M}$, and 3.0 M were selected. (3) Each molality corresponds to six different volume ratios. The volume ratios of bacteria solution and calcium source solution were $1: 0.5,1: 1,1: 2,1$ : $3,1: 4$, and $1: 5$, respectively. The volume of bacterial liquid was $5 \mathrm{ml}$, and the volume of calcium source solution was $2.5 \mathrm{ml}, 5 \mathrm{ml}, 10 \mathrm{ml}, 15 \mathrm{ml}, 20 \mathrm{ml}$, and $25 \mathrm{ml}$, respectively. (4) Using disposable plastic cups as experiment mold, first, pour the calcium source solution at each molar concentration into a plastic cup; then, take $5 \mathrm{ml}$ bacteria solution with $10 \mathrm{ml}$ titration tube and drop it into the calcium source solution in all cups, and make the bacteria solution react with calcium source solution at room temperature for 3-5d. Finally, the excess supernatant after the reaction was filtered out, and the elimination of metabolites was removed. Then, it was airdried for 3-5 d until it was completely dried. The quality of white calcium precipitation was weighed to determine the appropriate amount of bacterial solution and calcium source solution. The white precipitate (Figure 2(f)) was dried for 7 days, and the white precipitate was dried and weighed. The white precipitate was ground into a powder and passed through a 200 mesh sieve. X-ray diffraction (XRD) was used to analyze the white precipitate with a wide-angle goniometer and a scanning angle of $20^{\circ}$ to $80^{\circ}$. The crystal lattice types were determined according to the diffraction lines of the crystal structure, as shown in Figure 3.

To identify the bacteria species, 16SrRNA sequencing was used (Sangon Biotech (Shanghai)Co., Ltd). The phylogenetic tree was constructed using the neighbor joining (NJ) method. 16Sr RNA gene sequence of the Staphylococcus strain has been deposited NCBI database.

\subsection{Observing Bacterial Colonies and Calcium Carbonate} Precipitates. Bacteria colonies and MICP were observed using scanning electron microscopy (SEM). After centrifuging $10 \mathrm{~mL}$ of activated bacteria solution at $4000 \mathrm{rpm}$ and 
TABLE 1: The particle size ranges of different grain groups.

\begin{tabular}{lcccccccc}
\hline Control group $(\mathrm{CG})$ & CG1 $(\mathrm{mm})$ & CG2 $(\mathrm{mm})$ & CG3 $(\mathrm{mm})$ & CG4 $(\mathrm{mm})$ & CG5 $(\mathrm{mm})$ & CG6 $(\mathrm{mm})$ & CG7 $(\mathrm{mm})$ & CG8 $(\mathrm{mm})$ \\
\hline Particle size range & $0.075 \sim 5$ & $0.075 \sim 1$ & $1 \sim 2$ & $0.5 \sim 1$ & $0.25 \sim 0.5$ & $0.1 \sim 0.25$ & $0.075 \sim 0.1$ & $<0.075$ \\
\hline
\end{tabular}

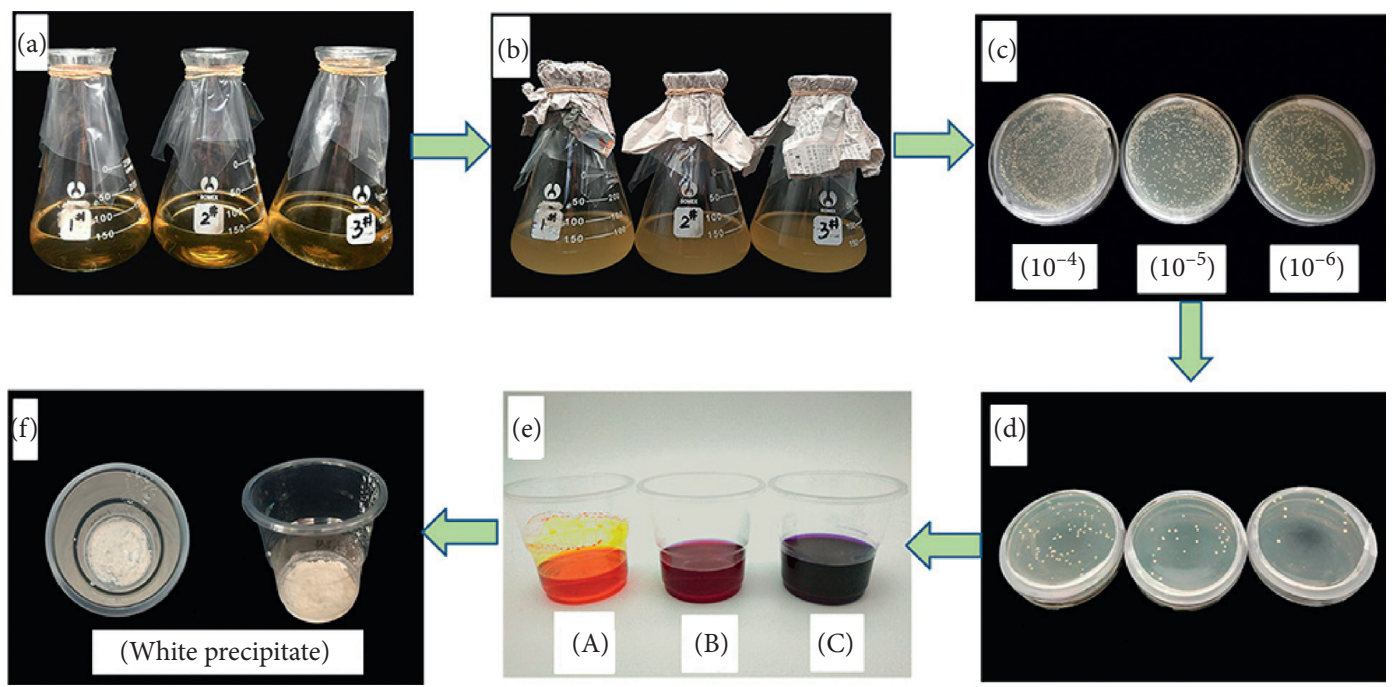

Figure 2: (a) Culture media. (b) Bacteria solution. (c) Separation strains. (d) Purified strains (single colony). (e) Change of culture media after adding acid-base indicator. (f) Verification of white precipitate.

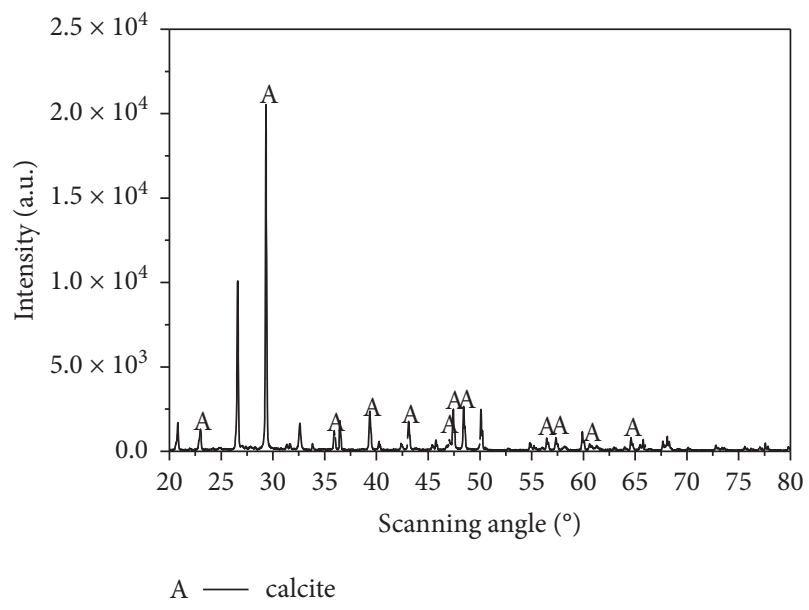

FIGURE 3: The analysis of X-ray diffraction bacterial identification.

draining the supernatant, the centrifuged bacteria were resuspended to produce an $\mathrm{OD}_{600}$ value less than 1 . Bacteria cell concentration in suspensions was determined by optical density measurements in a spectrophotometer at $600 \mathrm{~nm}$ $\left(\mathrm{OD}_{600}\right)$. The bacteria were suspended in $0.9 \% \mathrm{NaCl}$ solution or sterile water. $10 \mu \mathrm{L}$ of bacteria solution was placed onto the object slide, spread, and air-dried for SEM observation.

2.4. Bacterial Growth Conditions. The optimal bacteria growth environment was investigated by changing the $\mathrm{pH}$ value, initial inoculation amount, temperature, and shaking frequency. Liquid medium with an $\mathrm{OD}_{600}$ of 1.0 and a bacteria load of $1 \%$ was incubated at $30^{\circ} \mathrm{C}$ with shaking for
$48 \mathrm{~h}[43,44]$. A $1 \mathrm{~mL}$ liquid of bacteria solution was transferred to four triangular flasks, each containing $100 \mathrm{~mL}$ of fresh media. The $\mathrm{OD}_{600}$ of the samples was measured every $3 \mathrm{~h}$ to determine the best environment.

2.5. The Method of Microbial. As shown in Figure 4, a microbial mineralization reactor (Figure 4)(a) was used, including specimen shelf, a cementing fluid holding box, and an oxygen pump $[33,37]$. The immersion method was adopted to allow the calcium source solution to freely permeate the specimen. Following Zhao's methods [37], five different dilutions were prepared to achieve $\mathrm{OD}_{600}$ of $0.5,1.0,1.5,2.0$, and 2.5 . The bacteria liquid was shaken for $48 \mathrm{~h}$ and centrifuged in a high-speed centrifuge for $20 \mathrm{~min}$ to remove the supernatant. Then, fresh medium was added and diluted to $\mathrm{OD}_{600}$ of $0.5,1.0,1.5,2.0$, and 2.5 , respectively. Standard sand and aeolian sandy soil (Figures 4(c) and 4(d)) were mineralized. The bacteria mixtures with sand were stirred well and placed in the geotechnical mold. Specimens were prepared (Figure 4(b)).

Different control groups of particle size were mineralized and the suitable particle size range of the bacteria strain was determined. Mineralization was carried out as described by Li et al. [34]. Unconfined compression strength (UCS) tests were run to evaluate the effect of different $\mathrm{OD}_{600}$ on the strength characteristics of each specimen. The specimen size was $40 \times 80 \mathrm{~mm}$. The unconfined compressive strength test [45] was carried out with strain controlled triaxial shear instrument at a loading rate of $1.5 \%$ per minute [33]. 

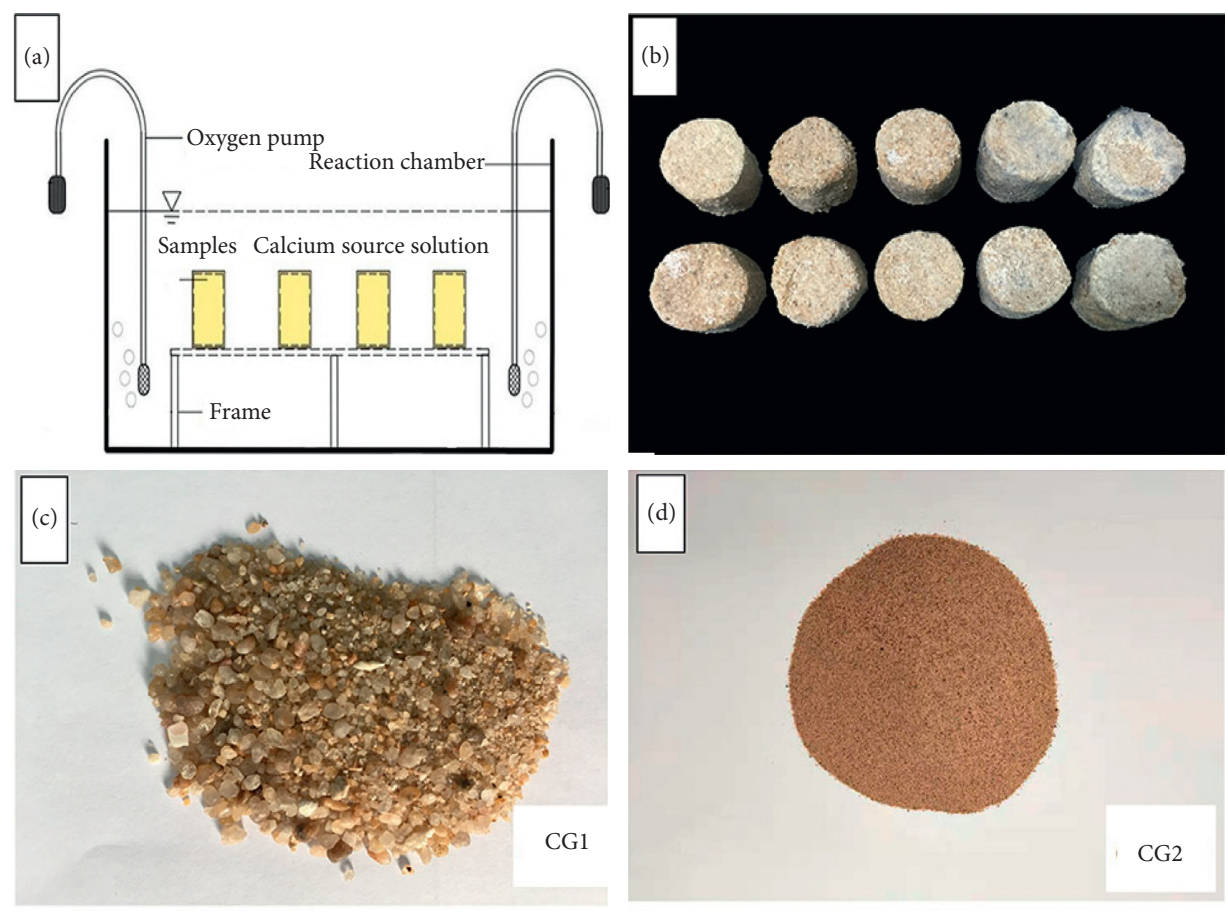

FIgURe 4: (a) Microbial mineralization reactor, (b) mineralization samples, (c) standard silica sand (CG1), and (d) Aeolian sandy soil (CG2).

2.6. Method of Biomineralization Crust in Desert Field Test. In order to verify the mineralization effect of autogenous mineralized bacteria (Staphylococcus) in the desert, Staphylococcus was applied to the desert surface to form in situ biomineralization crust based on MICP technology in this paper. Meanwhile, the crust effects of the two strains (Staphylococcus and Sporosarcina pasteurii) were compared. Refer to Zhao [36] for the culture method of Sporosarcina pasteurii.

The test site was located in the Ulan Buh desert of the Inner Mongolia Autonomous Region. The experimental area was $1.65 \mathrm{~m} \times 1.3 \mathrm{~m}$. Visual glass plates were embedded around the area to facilitate observation of the mineralization effect. Spraying device was used in field experiments. The spraying velocity of the solution can be adjusted. According to the existing laboratory research, the amount of bacteria solution and calcium source solution used in the field experiment was calculated [35]. A total of $43.5 \mathrm{~L}$ of bacteria liquid was sprayed only on the first day. And calcium source solution was injected into the desert soil at $108.75 \mathrm{~L} / \mathrm{d}$ for a total of 4 days. The spraying velocity of the bacteria solution was $0.012 \mathrm{~L} / \mathrm{s}$ and that of calcium source solution was $0.048 \mathrm{~L} / \mathrm{s}$. The bacteria solution and the calcium source solution were sprayed alternately. The volume ratio was $1: 5$ between the bacteria solution and the calcium source solution, and the volume ratio between the bacteria solution and the wind-sand soil was $1: 2$. After the calcium source solution was all sprayed and the surface water evaporated, the biomineralization crust was completely dried and the site detection was carried out. The penetration resistance of the crust layer was measured on days 7 and 210 by a portable penetration instrument. A portable penetration instrument is a kind of portable in situ measurement instrument. The probe diameter of the penetration instrument was $10 \mathrm{~mm}$, and the penetration resistance was recorded when the probe was vertically penetrated into the crust of different depths with constant pressure at a speed of $1 \sim 1.5 \mathrm{~m} / \mathrm{s}$. The instrument is portable, with electronic intelligence of $30 \mathrm{~cm}$. Its characteristic is that it does not need to collect soil and can be tested directly on the spot and in situ without disturbing the soil. Its detection depth is $30 \mathrm{~cm}$. The penetration resistance value should be averaged after a multipoint test under the same depth. The small pieces of biomineralization crust were taken with a geotechnical knife, and the excess standard solution of hydrochloric acid was used to react with the calcium carbonate in the crust layer by titration method. Then the residual hydrochloric acid was dripped back with the standard solution of sodium hydroxide, and the content of the calcium carbonate induced in the sample was calculated according to the difference.

\section{Results and Discussion}

3.1. Identifying Bacterial Strain. The autogenous strain was named gyl\#. The NJ method was used to construct the phylogenetic tree, as shown in Figure 5. The strain was highly homologous with Staphylococcus. Therefore, this bacteria is called autogenous Staphylococcus. The strain has been collected in China General Microbiological Culture Collection Center (CGMCC NO .15633). 16S rRNA gene sequence of the Staphylococcus strain has been deposited NCBI database, and the nucleotide sequence was SUB6617358. The accession number was MN736493.

SEM was used to observe bacterial colony morphology (Figures 6(a) and 6(b)). Bacterial division in the flourishing period was evident. SEM observations revealed uniform 


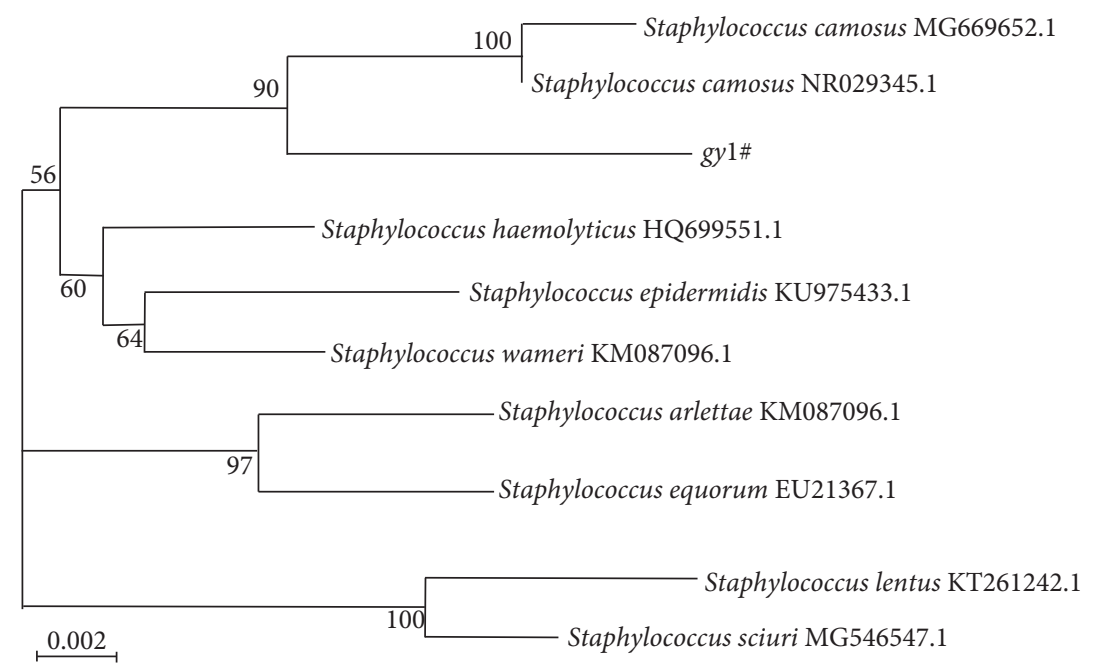

Figure 5: The phylogenic tree.

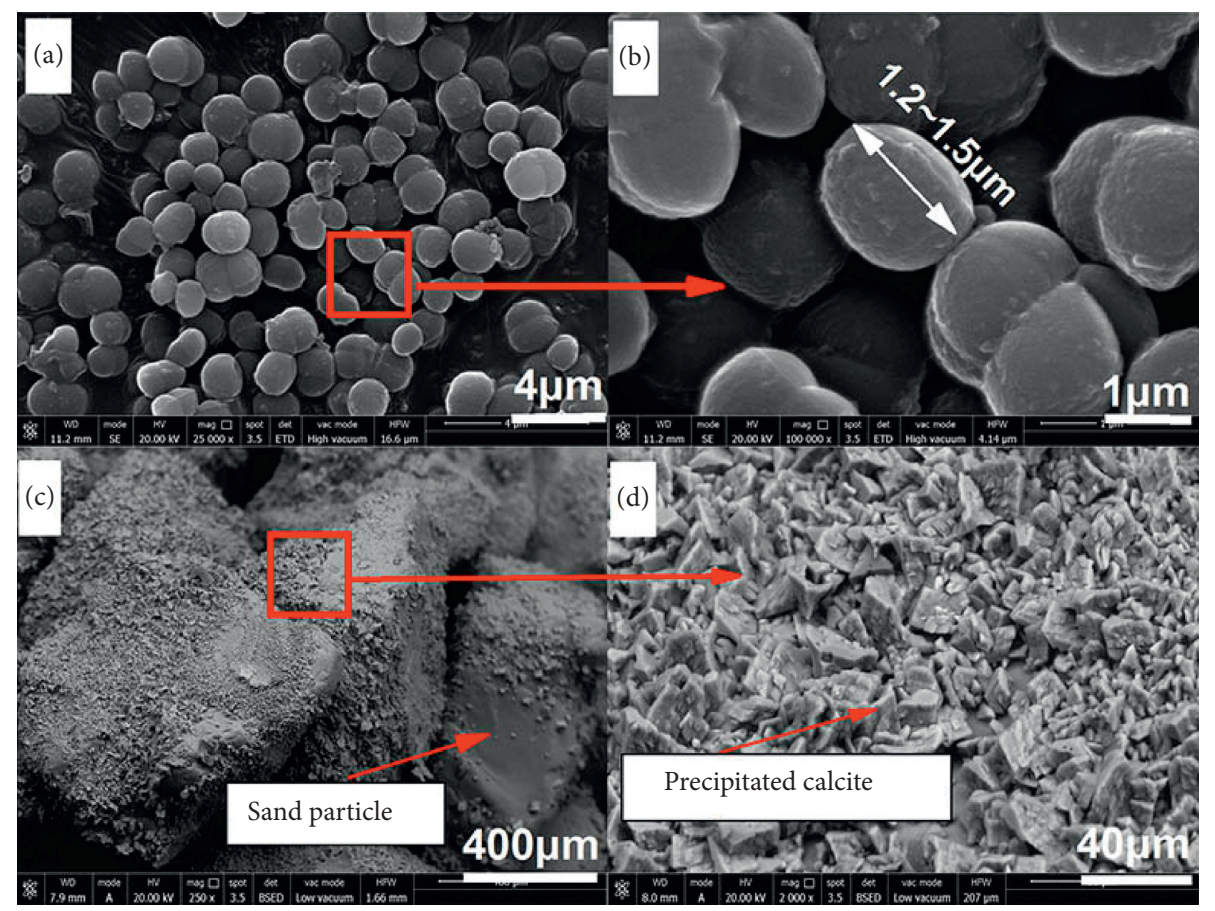

Figure 6: SEM images: (a) Staphylococcus. (b) The shape of Staphylococcus at magnification. (c) The surface and surrounding of the particles are filled with calcium carbonate. (d) Precipitated calcium carbonate induced by microorganism.

bacterial size with an average diameter of 1.2 to $1.5 \mu \mathrm{m}$, a spherical or ovoid bacterial shape, a smooth bacterial surface, and grapelike colonies. The number of bacteria in $100 \mathrm{~mL}$ of liquid was estimated to be $1.0 \times 10^{8}$ to $2.5 \times 10^{9}$.

\subsection{Appropriate Conditions for Bacterial Growth.} Temperature affects biochemical reactions inside bacteria, influencing their ability to survive and reproduce. Many soil microorganisms can survive in temperatures ranging from $15^{\circ} \mathrm{C}$ to $45^{\circ} \mathrm{C}$, with optimal growth between $25^{\circ} \mathrm{C}$ and $35^{\circ} \mathrm{C}$ [46]. Therefore, four temperatures $\left(25^{\circ} \mathrm{C}, 30^{\circ} \mathrm{C}, 35^{\circ} \mathrm{C}, 40^{\circ} \mathrm{C}\right)$ were selected for temperature optimization. As shown in
Figure $7(\mathrm{a})$, at $40^{\circ} \mathrm{C}$, the $\mathrm{OD}_{600}$ peaked at 1.07 ; growth was rapid, but the number of cells was significantly less than at the other three temperatures, with $26 \%$ fewer cells than that at $35^{\circ} \mathrm{C}$. At $25^{\circ} \mathrm{C}$, the lag phase of growth was longer; $6 \mathrm{~h}$ after entering the logarithmic phase, the $\mathrm{OD}_{600}$ peaked at 1.42 . Microbial growth was inhibited at low temperatures, while growth was rapid at high temperatures. Bacterial cell counts reached a maximum $\mathrm{OD}_{600}$ value at $35^{\circ} \mathrm{C}$. This temperature $35^{\circ} \mathrm{C}$ was appropriate for bacterial growth; the entire cell growth cycle was evident.

As shown in Figure 7(b), the $\mathrm{pH}$ of the bacteria solution varied. After $24 \mathrm{~h}$ of incubation, the bacterial solutions had $\mathrm{pH}$ peak values of 9.6; after $27 \mathrm{~h}$ of incubation, the $\mathrm{pH}$ value 

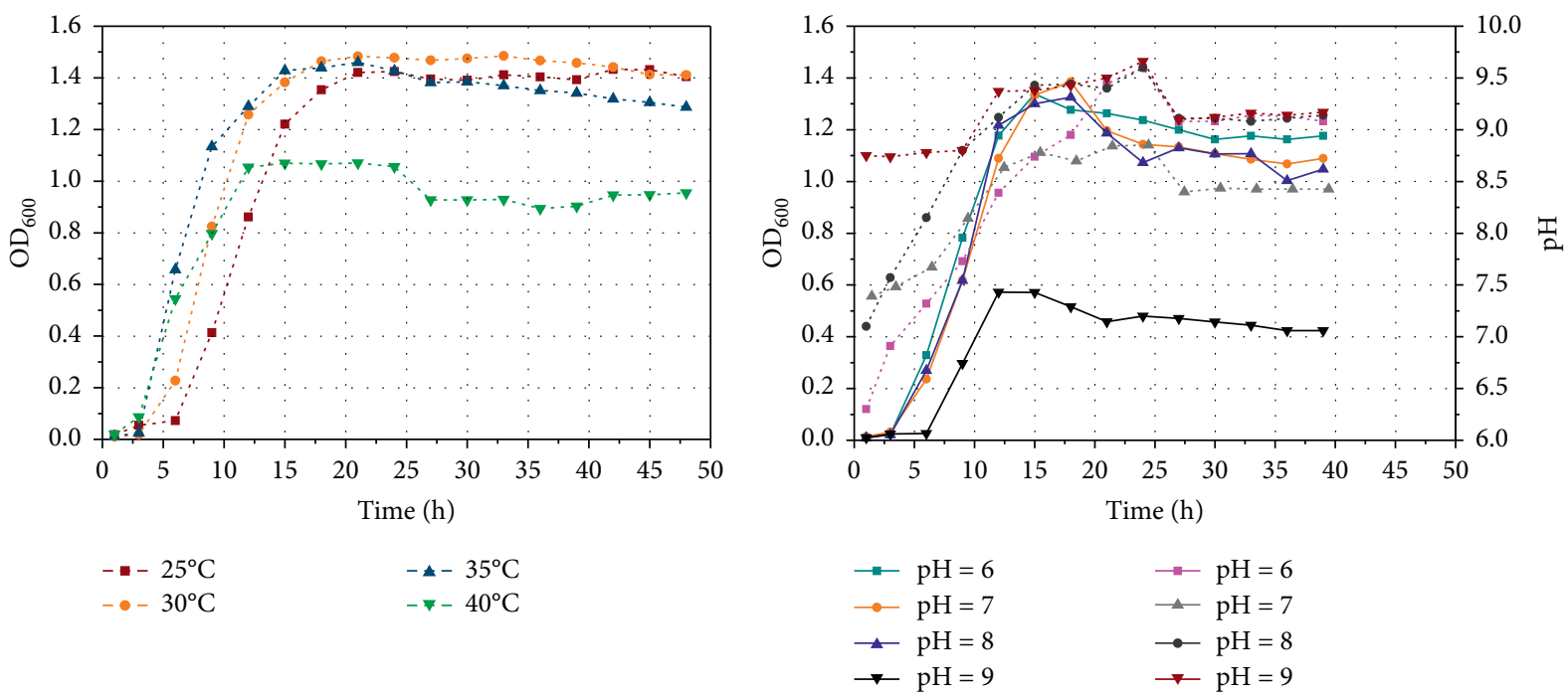

(a)

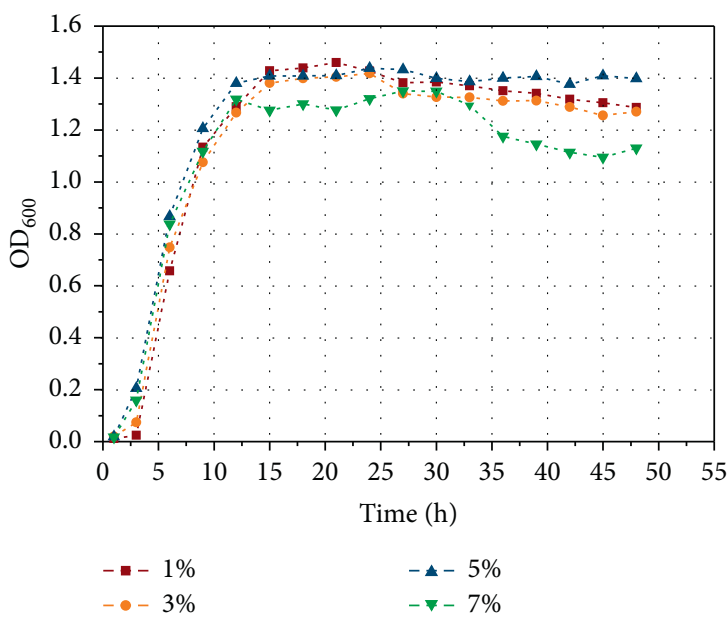

(c)

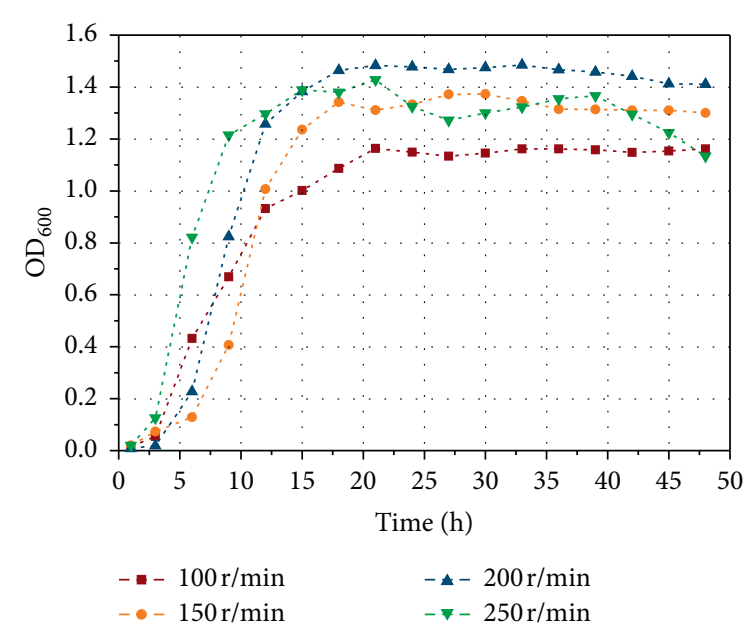

(d)

Figure 7: (a) The effect of temperature on bacterial growth; (b) the effect of $\mathrm{pH}$ on bacterial growth; (c) the effect of bacterial inoculation volume on bacterial growth; (d) the effect of shaker speed on bacterial growth.

was reduced to 9.14 and stabilized. This demonstrated the ability of the bacteria to degrade urea. At $\mathrm{pH} 7$ and 8 , bacterial growth was reduced, and at $\mathrm{pH} 6$ the bacterial concentration increased and plateaued. This indicates that this microorganism was alkali-resistant, with $\mathrm{pH}$ values of 6 to 8 being suitable for its growth and reproduction. This result was also verified in Figure 2(e). The initial light red color indicated a $\mathrm{pH}$ of 6.4 and a purple color indicated a $\mathrm{pH}$ of 9.0; $\mathrm{pH}$ value change from an acidic environment to an alkaline environment is illustrated and was caused by the bacteria degrading urea. This change in the microbial environment promotes the survival of alkali-resistant strains. Stocks-Fischer et al. [2] determined that MICP takes place between $\mathrm{pH} 8.3$ and 9.0, increasing with higher $\mathrm{pH}$ values.

As shown in Figure $7(\mathrm{c})$, a $7 \%$ inoculation volume of bacteria liquid provided the fastest growth rate in the lag phase of growth. While this large inoculation amount shortened the time to the logarithmic phase of bacterial growth, it also produced significantly fewer bacterial cells than the other three inoculation amounts. A $1 \%$ inoculation volume led to slower bacterial decay, with $11.5 \%$ more cells compared to a $7 \%$ inoculation volume. The inoculation volume affected the rate of growth and reproduction of the bacteria in culture.

Figure $7(d)$ shows the effect of four different shaking speeds on bacterial growth. Increasing the shaking speed caused the concentration of bacteria to increase. A rotation of $100 \mathrm{rpm}$ produced a long and slow logarithmic phase; the relatively slow speed limited the available oxygen and inhibited bacterial growth. At $250 \mathrm{rpm}$, the bacteria entered the growth period after $3 \mathrm{~h}$, but the logarithmic phase was unstable. A shaking speed of $200 \mathrm{rpm}$ allowed optimal bacterial growth. To summarize, bacterial growth was suitable at $35^{\circ} \mathrm{C}$ and $\mathrm{pH} 6$ with a $1 \%$ inoculation volume and shaking at $200 \mathrm{rpm}$. The bacteria grew slowly for $6 \mathrm{~h}, \log$ arithmically from 6 to $20 \mathrm{~h}$, and finally stabilized after $20 \mathrm{~h}$ (Figures $7(\mathrm{a})-7(\mathrm{~d}))$. 
Growth of Sporosarcina pasteurii was optimal at $30^{\circ} \mathrm{C}$ and $\mathrm{pH} 8-9$, similar to the optimal conditions observed for Staphylococcus. Sporosarcina pasteurii reached maximum cell numbers after $38 \mathrm{~h}$ [44]. The concentration of bacteria in Staphylococcus can reach the peak after $12 \sim 15 \mathrm{~h}$ in the growth process, which greatly shortens the experiment time compared with the Sporosarcina pasteurii. Optimal bacterial growth was observed at $35^{\circ} \mathrm{C}$ and $\mathrm{pH} 6$ with a $1 \%$ inoculation volume and shaking at $200 \mathrm{rpm}$.

\subsection{The Suitable Volume Proportion of the Bacterial Solution} and Calcium Source Solution. After 7 days, the white material was mainly calcium carbonate crystal, and the crystal was determined to be type A calcite (Figure 3 ). The volume ratios of bacteria solution to be tested were shown in Figure 8 with $2.5 \mathrm{~mol} / \mathrm{L}$ calcium and $1: 5$ ratio of bacteria solution to calcium source solution; $2.64 \mathrm{~g}$ of white precipitate was collected. This was the maximum white precipitate observed, 4.25 times higher than the precipitate generated with a ratio of $1: 0.5$. With the increase of calcium source solution, the volume ratio increased linearly from $1: 0.5$ to $1: 3$ and changed significantly from $1: 4$ to $1: 5$. At $3 \mathrm{~mol} / \mathrm{L}$ calcium and $1: 4$ and $1: 5$ ratio of bacteria solution to calcium source solution, the quantity of white precipitate declined sharply, indicating that the high calcium concentration inhibited MICP. The calcium ion concentration should not exceed $2.5 \mathrm{~mol} / \mathrm{L}$. There was a gradual increase in white precipitate as the volume ratio of the bacteria solution to the calcium source solution increased from $1: 0.5$ to $1: 5$.

Zhao [44] found that Sporosarcina pasteurii produced more calcium carbonate at higher calcium ion concentrations. Calcium chloride and urea concentrations above $1.5 \mathrm{M}$ caused a rapid decrease in the production of calcium carbonate, suggesting that high calcium carbonate concentrations may significantly inhibit enzyme activity. However, the mineralization effect of Staphylococcus was suitable for calcium sources of high concentration.

3.4. The Suitable Concentration of Bacteria Solution for the Mineralization Specimen. Many scholars have experimented with Sporosarcina pasteurii to improve the strength and stiffness of sandy soil and to control the permeability and porosity of sandy soil, with research primarily focused on noncohesive loose soil [1, 28, 47-49]. Bacteria cells are typically 0.5 to $3 \mu \mathrm{m}$ in diameter, while bacteria spores, stress-resistant resting stages in some species, can be as small as $0.2 \mu \mathrm{m}$ in diameter [50]. Due to their small size, microorganisms can move freely in the pores of coarse-grained materials. Therefore, this study investigated the effect of mineralization of sandy soil on its porosity.

CG1 and CG2 were prepared at $\mathrm{OD}_{600} 0.5,1.0,1.5,2.0$, 2.5, and 3.0 with $0.5 \mathrm{M}$ calcium. As shown in Figure 9, the UCS of CG1 and CG2 increased with increasing bacterial concentrations. At $3.0\left(\mathrm{OD}_{600}\right)$, a large amount of calcium carbonate appeared on the surface of the mold due to the high bacterial concentration, and the mold was tightly bound to the specimen. As a result, it was difficult to remove the mold and the specimen surface had mold fibers even after the mold was demolded. Increasing the bacterial concentration from an $\mathrm{OD}_{600}$ of 0.5 to 2.5 caused the UCS of CG1 to increase from $0.73 \mathrm{MPa}$ to $4.33 \mathrm{MPa}$ (a 4.93 -fold increase). Over the same bacterial concentrations, the UCS of CG2 increased 2.96-fold, from $0.5 \mathrm{MPa}$ to $1.98 \mathrm{MPa}$. When $\mathrm{OD}_{600}$ was 1.0 , UCS of CG1 and CG2 increased, respectively, by $201 \%$ and $21 \%$ compared with that of $0.5\left(\mathrm{OD}_{600}\right)$; the growth rate was more obvious. When $\mathrm{OD}_{600}$ was 2.5, the growth rate of UCS was less than that of 2.0 $\left(\mathrm{OD}_{600}\right)$ with little change, indicating a suitable Staphylococcus at $\mathrm{OD}_{600} 1.0$ to 2.0.

The SEM of the mineralized specimens were shown in Figures 6(c) and 6(d). Mineralization causes calcium carbonate crystal to appear on the surface of sand grains (Figure 6)(c), with some crystal overlap(Figure 6)(d). The calcium carbonate bonds sand particles together and increases the density of the sand. Although Staphylococcus is common in nature, the newly screened strain of Staphylococcus demonstrated that it has a strong mineralization function and has promising research and geotechnical applications. Traditional Sporosarcina pasteurii is the most commonly used MICP technique in geotechnical engineering [17, 28, 32, 51]. Autogenic Staphylococcus is also possible to solidify geotechnical matrix materials.

3.5. Evaluating Soil Particle Size Range. In the existing studies on MICP, many research works were also conducted on coarse sand and fine sand using Sporosarcina pasteurii $[28,32,33,51,52]$. It is also a key point of this study whether bacteria can be well applied in fine soil. After the MICP technology solidified, the pores of the sand body were filled with a large amount of calcium carbonate, and the permeability coefficient was reduced by 2-3 orders of magnitude [25]. bacteria and calcium source solution were injected into the sand at a volume ratio of $1: 1$, with $2 \mathrm{~mol} / \mathrm{L}$ calcium chloride and $2 \mathrm{~mol} / \mathrm{L}$ urea. Sand samples with particle sizes between 0.25 and $0.5 \mathrm{~mm}$ showed the best overall performance after curing. The curing effect on coarse samples (particle size $>2 \mathrm{~mm}$ ) and fine samples (particle size $<0.075 \mathrm{~mm}$ ) was weak due to the intergranular porosity, permeability, and other factors. The influence of sand particle size on MICP was analyzed using a dry density experiment and a seepage experiment [53]. Staphylococcus is spherical or ellipsoid and usually clusters into clusters of grapes. Sporosarcina pasteurii is rod-shaped. Until then, it had not worked well in mineralized fine-grained soils $[1,34]$.

In this study, UCS was tested to investigate the effect of autogenous bacteria on the sandy soil of different particle sizes, with results shown in Figure 10. The UCS of CG1 was 1.756 MPa after curing; curing caused white crystals to appear on and around the surface of sand grains of the solidified specimen, compacting the sample and increasing its overall strength. In contrast, the UCS of CG3 was only $0.88 \mathrm{MPa}$. This sample had large pores between sand particles and small contact area between particles, making it difficult to fill the pores with calcium carbonate, resulting in poor mineralization and low strength. The UCS of CG4 reached a maximum of $1.537 \mathrm{MPa}$. This specimen had 


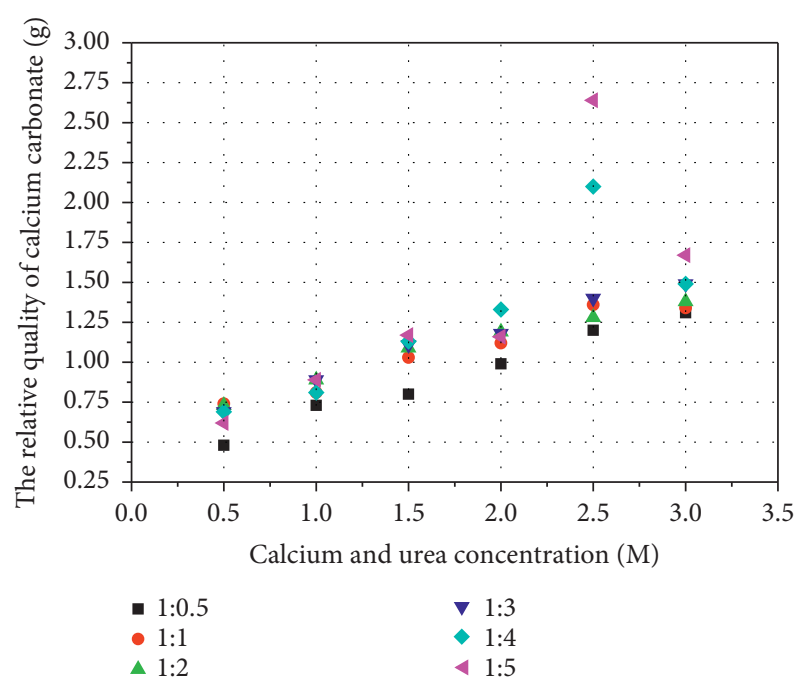

FIGURE 8: The relative quality of calcium carbonate at different calcium and urea concentration sources.

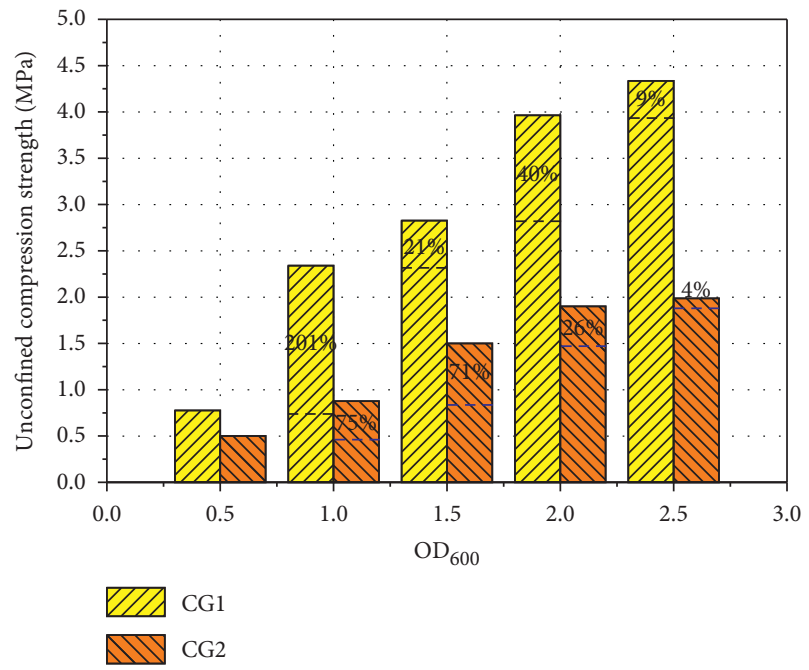

FIGURE 9: Unconfined compression strength (UCS) of standard silica sand (CG1) and Aeolian sandy soil (CG2).

uniform solidification without fluffiness or particle shedding. The UCS of CG4, CG5, and CG6 exceeded 1.0 MPa, while the UCS of CG8 was $0.43 \mathrm{MPa}$. CG8 had particle size slightly smaller than the range of 0.5 to $1 \mathrm{~mm}$, limiting the UCS after mineralization, but the forming effect after the overall mineralization was better.

In the experiment, a microbial mineralization reactor was used to permeate calcium source solution from the specimen. This free penetration method was simple and easy to operate, and the calcium solution did not need to be injected throughout the experiment. The MICP results at $0.5 \mathrm{~mol} / \mathrm{L}$ calcium chloride and urea indicate that a high calcium source concentration was not required for mineralization. As shown in Figure 10, the best curing was observed with particle sizes 0.1 to $1 \mathrm{~mm}$, in samples CG4, CG5, and CG6. Aeolian sandy soil with particle sizes between 0.1 and $0.5 \mathrm{~mm}$ accounted for $88.2 \%$ of the total mass of the specimens, and the UCS of CG3 was $0.88 \mathrm{MPa}$. This indicates that desert Staphylococcus had a significant mineralization effect on Aeolian sandy soil, and that this autogenous bacteria can be used as a natural agent for soil mineralization. Different from Sporosarcina pasteurii, Staphylococcus is smaller in diameter and easier to pass through the pores between fine particles in which calcareous connections are formed. The UCS results well verify that the autogenous Staphylococcus can adapt to the desert environment.

3.6. Desert Field Experimental of Biomineralization Crust. Due to the special natural environment of the Ulan Buh desert, the wind erosion was strong with the wind speed of $4.1 \mathrm{~m} / \mathrm{s}$. Wind-sand hazard was the main natural disaster. Desert wind erosion has seriously affected the ecological environment of the desert [38, 40,52, 54]. The wind erosion of the biomineralization crust was continued to track and monitor in the later period. After the formation of the biomineralization crust of the autogenous Staphylococcus and Sporosarcina pasteurii, white crystal appeared on the surface and the surface hardness increased. After 210 days, the two crust layers were damaged and peeled (Figures 11(a)-11(d)). The average thickness of the Staphylococcus mineralization crust decreased from the original $2 \sim 2.4 \mathrm{~cm}(7 \mathrm{~d})$ to $1.8 \sim 2.3 \mathrm{~cm}(210 \mathrm{~d})$, and the content of calcium carbonate decreased from $14 \%$ to $13 \%$. The average thickness of the Sporosarcina pasteurii mineralization crust decreased from the original $2 \sim 2.5 \mathrm{~cm}(7 \mathrm{~d})$ to $0.7 \sim 1.0 \mathrm{~cm}$ $(210 \mathrm{~d})$ and the content of calcium carbonate decreased from $13 \%$ to $9 \%$. In the long-term detection, it was found that the effect of Staphylococcus crust effect was better than Sporosarcina pasteurii after natural wind erosion, and the content of calcium carbonate changed a little in the Staphylococcus crust layer.

As can be seen from Figures 11(e) and 11(f), the average penetration resistance at different detection times varies with the testing depth in the mineralization crust of the two bacteria. With the increase of testing days, the strength of the crust layer increased with time. In Figure 11(g), the mineralization rate increased rapidly 7 days ago, and the strength of the crust still increased after 7 days, but the growth rate slowed down, the strength of the crust has been reduced to varying degrees in the late stage. The strength of Sporosarcina pasteurii mineralization crust was 19\% lower than that of autogenous Staphylococcus.

According to the instrument specification [55], the average penetration resistance at a depth of $2 \mathrm{~cm}$ was converted into the strength of the crust. The strength of Sporosarcina pasteurii crust at 7 days was $157.1 \mathrm{KPa}$ and decreased to $122 \mathrm{KPa}$ at 210 days. The strength of Staphylococcus crust at 7 days was $161 \mathrm{KPa}$ and decreased to $157 \mathrm{KPa}$ at 210 days. The ratio of the penetration resistance on 210 days to 7 days was defined as the influence coefficient $(R)$ on the strength stability of crust. The influence coefficient $(R)$ of the strength stability (Staphylococcus) was 0.99 . The results showed that there was no significant change in the strength of the crust after 7 months. The influence coefficient $(R)$ on the strength and stability of the crust of Sporosarcina pasteurii was 0.813 . 


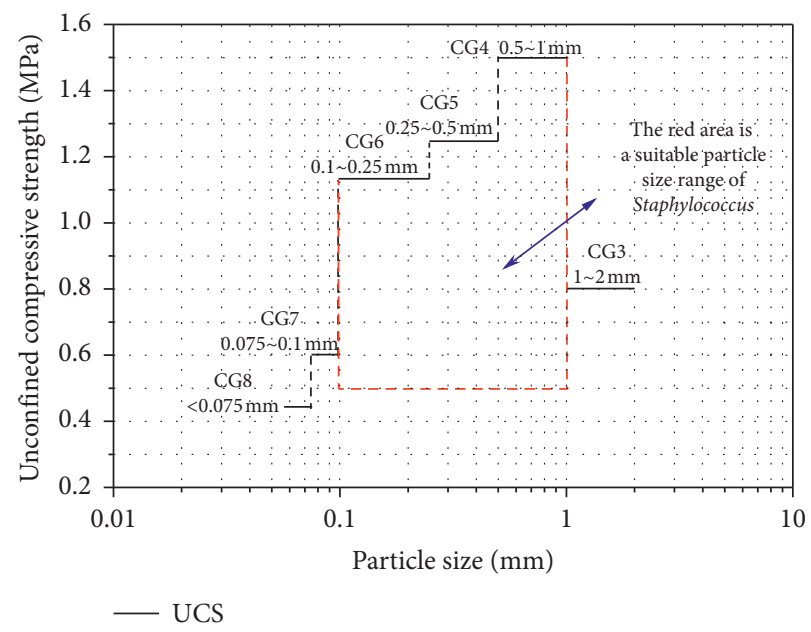

FIGURE 10: Unconfined compression strength (UCS) of different control group (CG).

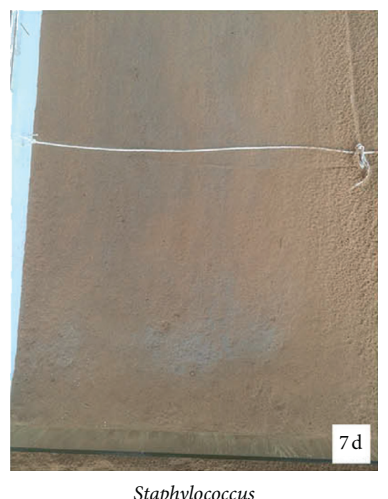

(a)

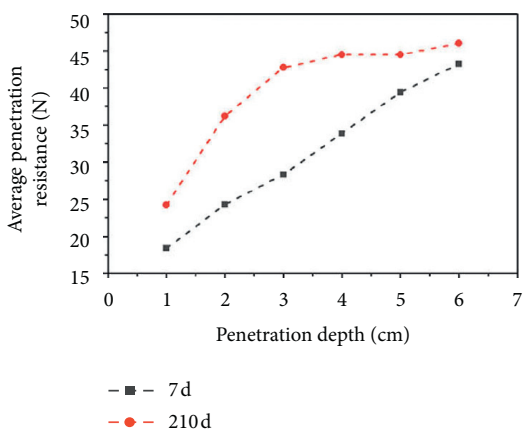

(e)

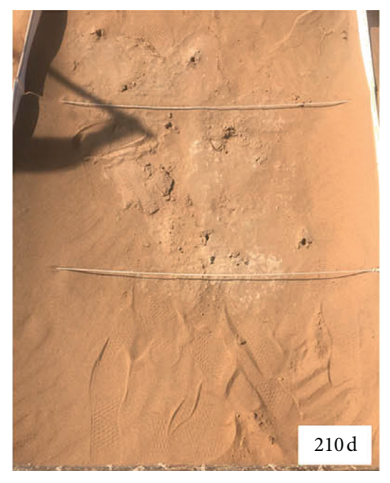

Staphlococcus

(b)

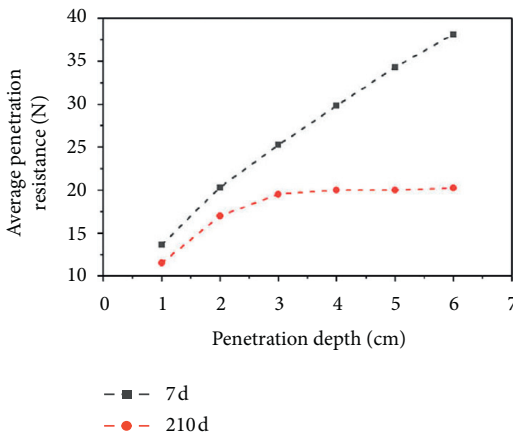

(f)

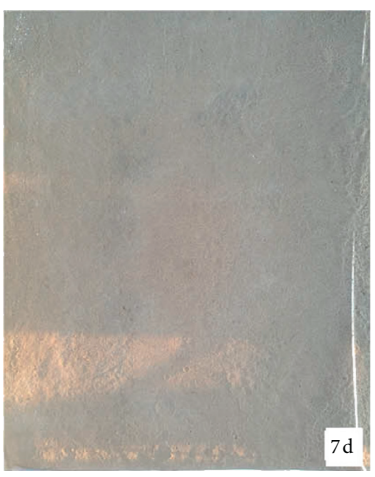

Sporosarcina pasteurii

(c)

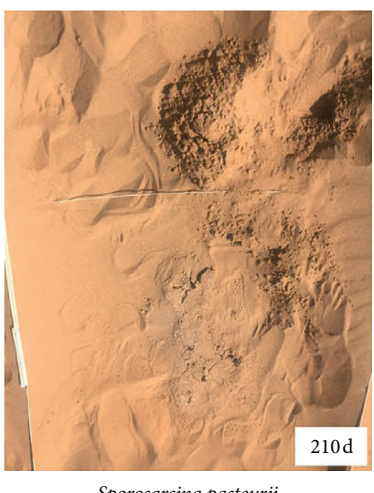

(d)

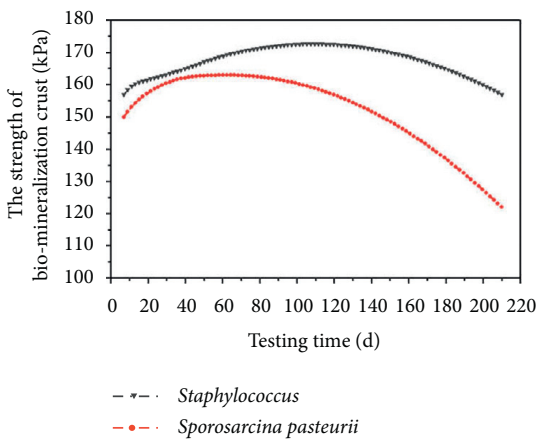

(g)

Figure 11: Field penetration test; (a) the crust effect (7 d Staphylococcus); (b) The crust effect (210 d Staphylococcus); (c) the crust effect ( $210 \mathrm{~d} \sim$ Sporosarcina pasteurii); (d) the crust effect ( $210 \mathrm{~d} \sim$ Sporosarcina pasteurii); (e) the penetration resistance changing (Staphylococcus); (f) the penetration resistance changing (Sporosarcina pasteurii); (g) the strength of biomineralization crust for Staphylococcus and Sporosarcina pasteurii.

It indicated that in the mineralization process of desert autogenous Staphylococcus, due to its diameter was smaller. It was more likely to pass through the fine soil particles and form stable calcium connections in the pores. Therefore, the long-term mineralization ability of autogenous Staphylococcus in the desert environment was stronger than that of
Sporosarcina pasteurii, and the biomineralization crust was more stable. Following the model of desert management and desertification control, it is a new breakthrough in special soil improvement technology under the background of the combination of green biotechnology and desert management. 


\section{Conclusion}

The purpose of this study is to extract mineralization strain from desert Aeolian sandy soil for the first time and to solidify Aeolian sandy soil. And the autogenous bacteria were applied to the mineralization crust experiment in the desert. Based on the previously mentioned, the following conclusions can be drawn:

(1) A bacterial strain was isolated and purified from desert Aeolian sandy soil and was identified as Staphylococcus. XRD analysis shows that the white precipitation produced by Staphylococcus mineralization is determined as calcium carbonate. Desert autogenous Staphylococcus is a few microorganisms with strong mineralization ability among autogenous strains. The optimal growth condition of Staphylococcus was observed at $35^{\circ} \mathrm{C}$ and $\mathrm{pH} 6$ with a $1 \%$ inoculation volume and shaking at $200 \mathrm{rpm}$.

(2) The calcium ion concentration should not exceed $2.5 \mathrm{~mol} / \mathrm{L}$. There is a gradual increase in white precipitate as the volume ratio of the bacteria solution to the calcium source solution increased from $1: 0.5$ to $1: 5$. The mineralization effect of Staphylococcus was suitable for calcium sources of high concentration. The UCS results show that the most suitable concentration range of Staphylococcus solution is 1.0 to $2.0\left(\mathrm{OD}_{600}\right)$, and the best curing effect on sand particle sizes range is 0.1 to $1 \mathrm{~mm}$.

(3) The autogenous desert Staphylococcus is applied to the desert surface for the first time to form biomineralization crust in situ, and the mineralization effect and the crust strength of the autogenous strain were studied. The long-term mineralization ability of autogenous Staphylococcus in the desert environment is stronger than that of Sporosarcina pasteurii, and the is more stable. Biomineralization by the autogenous Staphylococcus can improve Aeolian sandy soil crust effects, prevent wind erosion of desert soil, and reduce the impact of foreign bacteria on the soil environment. This model has great promise for desert management. It can provide an experimental basis for the extension and application of the strain in desert management.

Future studies could investigate the pore structure of sandy soil and the mechanism of mineralization. The weather resistance of mineralized materials will be studied in more detail because of the cold and dry climate of the desert.

\section{Data Availability}

The experimental data used to support the findings of this study are available from the corresponding author upon request.

\section{Conflicts of Interest}

The authors declare that they have no conflicts of interest.

\section{Acknowledgments}

This study was sponsored by the Natural Science Foundation of China (Nos. 51668050 and 51968057) and Natural Science Foundation of Inner Mongolia (Nos. 2019MS05072 and 2019MS05075). This work was also funded by a grant from Major Science and Technology Projects of Inner Mongolia Autonomous Region (Grant no. 2019ZD002).

\section{References}

[1] J. T. DeJong, M. B. Fritzges, and K. Nüsslein, "Microbially induced cementation to control sand response to undrained shear," Journal of Geotechnical and Geoenvironmental Engineering, vol. 132, no. 11, pp. 1381-1392, 2006.

[2] F. S. Stocks, J. K. Galinat, and S. S. Bang, "Microbiological precipitation of $\mathrm{CaCO}_{3}$," Soil Biol Biochem, vol. 31, pp. 1563-1571, 1999.

[3] B. C. Martinez and J. T. DeJong, "Bio-mediated soil improvement: load transfer mechanisms at the Micro-and-Macro scales," in Proceedings of the 2009 US-China Workshop on Ground Improvement Technologies, pp. 242-251, Orlando, FL, USA, March 2009.

[4] N. W. Soon, L. M. Lee, T. C. Khun, and H. S. Ling, "Factors affecting improvement in engineering properties of residual soil through microbial-induced calcite precipitation," Journal of Geotechnical and Geoenvironmental Engineering, vol. 140, Article ID 04014006, 2014.

[5] T. J. Weaver, M. Burbank, A. Lewis, and R. Lewis, "Bio-induced calcite, iron, and manganese precipitation for geotechnical engineering applications," in Proceedings of the Geo-Frontiers, pp. 3984-3992, ASCE, Dallas, TX, USA, March 2011.

[6] A. B. Cunningham, W. G. Characklis, F. Abedeen, and D. Crawford, "Influence of biofilm accumulation on porous media hydrodynamics," Environmental Science \& Technology, vol. 25, no. 7, pp. 1305-1311, 1991.

[7] G. Ranalli, M. Matteini, I. Tosini, E. Zanardini, and C. Sorlini, "Bioremediation of cultural heritage: removal of sulphates, nitrates and organic substances," Microbes and Art, Springer, New York, NY, USA, pp. 231-245, 2000.

[8] M. A. D. De Rienzo, P. S. Stevenson, R. Marchant, and I. M Banat, "Effect of biosurfactants on Pseudomonas aeruginosa and Staphylococcus aureus biofilms in a bio-flux channel," Applied Microbiology and Biotechnology, vol. 100, pp. 5773-5779, 2016.

[9] J. T. DeJong, K. Soga, E. Kavazanjian et al., "Biogeochemical processes and geotechnical applications: progress, opportunities and challenges," Géotechnique, vol. 63, no. 4, pp. 287-301.

[10] M. G. Gomez, B. C. Martinez, J. T. DeJong et al., "Field-scale bio-cementation tests to improve sands," Proceedings of the Institution of Civil Engineers-Ground Improvement, vol. 168, no. 3, pp. 206-216, 2015.

[11] E. Salifu, E. Maclachlan, K. R. Iyer, C. W. Knapp, and A. Tarantino, "Application of microbially induced calcite precipitation in erosion mitigation and stabilisation of sandy soil foreshore slopes: a preliminary investigation," Engineering Geology, vol. 201, pp. 96-105, 2016.

[12] I. Karatas, E. Kavazanjian, and B. E. Rittmann, "Microbially induced precipitation of calcite using Pseudomonas Denitrificans," in Proceedings of the 1st International Conference on Bio-Geo-Civil Engineering, pp. 58-66, Delft, Netherlands, June 2008. 
[13] M. P. Harkes, L. A. Van Paassen, and J. L. Booster, "Fixation and distribution of bacterial activity in sand to induce carbonate precipitation for ground reinforcement," Ecological Engineering in Proceedings of the 1st International Conference on Bio Geo Civil Engineering, vol. 36, no. 2, pp. 112-117, Delft, Netherlands, June 2010.

[14] V. P. Pham, A. Nakano, D. S. Van, and R. Wouter, "Applying MICP by denitrification in soils: a process analysis," Environmental Geotechnics, vol. 5, no. 2, pp. 79-93, 2018.

[15] N. Jiang, C. S. Tang, T. Hata, B. Courcelles, O. Dawoud, and D. N. Singh, "Bio-mediated soil improvement: the way forward," Soil Use and Management, vol. 36, no. 2, pp. 185-188, 2020.

[16] K.-W. Liu, N.-J. Jiang, J.-D. Qin, Y.-J. Wang, C.-S. Tang, and X.-L. Han, "An experimental study of mitigating coastal sand dune erosion by microbial- and enzymatic-induced carbonate precipitation," Acta Geotechnica, 2020.

[17] V. Ivanov, J. Chu, and V. Stabnikov, "Iron-based bio-grout for soil improvement," in Proceedings of the 2nd International Conference Sustainable Construction Materials and Technologies, pp. 415-420, Ancona, Italy, June 2010.

[18] J. Chu, V. Stabnikov, and V. Ivanov, "Microbially induced calcium carbonate precipitation on surface or in the bulk of soil," Geomicrobiology Journal, vol. 29, no. 6, pp. 544-549, 2012.

[19] L. Cheng, Y. Yang, and J. Chu, "In-situmicrobially induced $\mathrm{Ca}^{2+}$-alginate polymeric sealant for seepage control in porous materials," Microbial Biotechnology, vol. 12, no. 2, pp. 324-333, 2018.

[20] F. Hammes, N. Boon, J. de Villiers et al., "Strain-specific ureolytic microbial calcium carbonate precipitation," Applied and Environmental Microbiology, vol. 69, no. 8, pp. 49014909, 2003.

[21] J. Dick, W. de Windt, B. de Graef et al., "Bio-deposition of a calcium carbonate layer on degraded limestone by Bacillus species," Biodegradation, vol. 17, no. 4, pp. 357-367, 2006.

[22] Z Yang, X. H. Cheng, and M. Li, "Engineering properties of MICP-bonded sandstones used for historical masonry building restoration," in Proceedings of the Geo-Frontiers, pp. 4031-4040, ASCE, Dallas, TX, USA, March 2011.

[23] X. N. Yu, C. X. Qian, and Wang, "Microbially induced deposition of barium phosphates and its ingredient, morphology and size under different $\mathrm{pH}$ values," Journal of Southeast University, vol. 31, pp. 506-510, 2015, in Chinese.

[24] X. Yu, C. Qian, and L. Sun, "The influence of the number of injections of bio-composite cement on the properties of biosandstone cemented by bio-composite cement," Construction and Building Materials, vol. 164, pp. 682-687, 2018.

[25] J. Chu, V. Ivanov, V. Stabnikov, and B. Li, "Microbial method for construction of an aquaculture pond in sand," Géotechnique, vol. 63, no. 10, pp. 871-875, 2013.

[26] M. G. Gomez, C. M. R. Graddy, J. T. DeJong, D. C. Nelson, and M. Tsesarsky, "Stimulation of native microorganisms for biocementation in samples recovered from field-scale treatment depths," Journal of Geotechnical and Geoenvironmental Engineering, vol. 144, Article ID 04017098, 2018.

[27] H. C. Chen, C. X. Qian, and L. F. Ren, "Self-healing of early age cracks incement-based materials based on mineralization of microorganism," Journal of Southeast University(Natural Science Edition, vol. 46, pp. 606-611, 2016.

[28] L. A. van Paassen, C. M. Daza, M. Staal, D. Y. Sorokin, W. van der Zon, and M. C. M. Van Loosdrecht, "Potential soil reinforcement by biological denitrification," Ecological Engineering, vol. 36, no. 2, pp. 168-175, 2010.
[29] M. W. De, N. D. Belie, and W. Verstraete, "Microbial carbonate pre cipitation in construction materials: a review," Ecological Engineering, vol. 36, pp. 118-136, 2009.

[30] J. T. DeJong, K. Soga, S. A. Banwart et al., "Soil engineering in vivo: harnessing natural biogeochemical systems for sustainable, multi-functional engineering solutions," Journal of the Royal Society Interface, vol. 8, no. 54, pp. 1-15, 2011.

[31] S. Zhang and X. H. Cheng, "Numerical simulation and experimental research on stabilization of liquefiable sand foundation by MICP," Industrial Architecture, vol. 23-27, p. 47, 2015, in Chinese.

[32] J. T. DeJong, B. M. Mortensen, B. C. Martinez, and D. C. Nelson, "Bio-mediated soil improvement," Ecological Engineering, vol. 36, no. 2, pp. 197-210, 2010.

[33] C. Whalley, S. H. Liu, T. J. Zhou, Y. Gao, and D. Yao, "The strength and porosity properties of MICP-treated Aeolian sandy soil," Mechanics in Engineering, vol. 39, pp. 165-171, 2017, in Chinese.

[34] H. Li, C. Li, T. Zhou, S. Liu, and L. Li, "An improved rotating soak method for MICP-treated fine sand in specimen preparation," Geotechnical Testing Journal, vol. 41, no. 4, pp. 805-814, 2018a.

[35] C. Li, D. Yao, S. Liu et al., "Improvement of geomechanical properties of bio-remediated aeolian sand," Geomicrobiology Journal, vol. 35, no. 2, pp. 132-140.

[36] Q. Zhao, L. Li, C. Li, H. Zhang, and F. Amini, "A full contact flexible mold for preparing samples based on microbial-induced calcite precipitation technology," Geotechnical Testing Journal, vol. 37, no. 5, pp. 917-921, 2014a.

[37] Q. Zhao, L. Li, C Li et al., "Factors affecting improvement of engineering properties of MICP-treated soil catalyzed by bacteria and urease," Journal of Materials in Civil Engineering, vol. 26, Article ID 04014094, 2014b.

[38] C. Li, H. Huang, L. Li, Y. Gao, F. Ma, and F. Amini, "Geotechnical hazards assessment on wind-eroded desert embankment in Inner Mongolia Autonomous Region, North China," Natural Hazards, vol. 76, no. 1, pp. 235-257, 2015a.

[39] C. Li, X. D. Ge, L. P. Gao, Y. F. Ma, and B. S. Huang, "Experimental studies on erosion mechanism of embankments subjected to wind and freeze-thaw compound erosion in cold and arid regions," Engineering Mechanics, vol. 32, pp. 177182, 2015b, in Chinese.

[40] C. Li and H. Yu, "Experimental studies of strength characteristics and solidified mechanism for solidified aeolian sandy soil," Rock and Soil Mechanics, vol. 30, no. 2, pp. 48-53, 2009, in Chinese.

[41] Y. H. Su and X. F Song, "Experimental studies on solidified sandy soil unconfined compressive strength," Journal of Inner Mongolia Agricultural University, vol. 32, no. 3, pp. 215-218, 2011, in Chinese.

[42] Y. Gao, D. Yao, X. Qin, and C. Li, "Study on freeze-thaw properties for microbial materials in salt corrosion environment," Journal of Disaster Prevention and Mitigation Engineering, vol. 38, pp. 787-794, 2018, in Chinese.

[43] Z. Y. Zhang, G. Y. Li, D. X. Ding, and Y. D. Wang, "Isolation and identification of a bacterial strain inducing mineralization of calcium carbonate," Journal of University of South China (Science and Technology), vol. 28, pp. 30-33, 2014.

[44] Q. Zhao and H. Z. Zhang, "Experimental study on soil improvement using microbial induced calcite precipitation (MICP)," Dissertation supervisor in Chinese, China University of Geosciences, Beijing, China, 2014. 
[45] ASTM, Standard Test Method for Unconfined Compressive Strength of Cohesive Soil, ASTM D6951, West Conshohocken, PA, USA, 2009.

[46] M. Alexander, Introduction to Soil Microbiology, pp. 472-428, Wiley, New York, NY, USA, 1961.

[47] F. Ferris, L. Stehmeier, A. Kantzas et al., "Bacteriogenic mineral plugging," Journal of Canadian Petroleum Technology, vol. 35, no. 8, pp. 56-61, 1996.

[48] V. S Whiffin, "Microbial $\mathrm{CaCO}_{3}$ precipitation for the production of biocement," Ph.D. dissertation, Murdoch University, Perth, Australia, 2004.

[49] A. A. Qabany and K. Soga, "Effect of chemical treatment used in MICP on engineering properties of cemented soils," Géotechnique, vol. 63, no. 4, pp. 331-339, 2013.

[50] J. K. Mitchell, J. C. Santamarina, and J. C. Santamarina, "Biological considerations in geotechnical engineering," Journal of Geotechnical and Geoenvironmental Engineering, vol. 131, no. 10, pp. 1222-1233, 2005.

[51] V. S. Whiffin, L. A. van Paassen, and M. P. Harkes, "Microbial carbonate precipitation as a soil improvement technique," Geomicrobiology Journal, vol. 24, no. 5, pp. 417-423, 2007.

[52] C. Li, S. Wang, Y. X. Wang, GaoY, and R. G. L. Si, "Field experimental study on stability of bio-mineralization crust in the desert," Rock and Mechanics, vol. 40, no. 4, pp. 1292-1298, 2019, in Chinese.

[53] Y. X. Ou, X. W. Feng, C. N. Shen, J. Li, and L. Y. Gao, "Influence of particle sizes of coral," Sand on Bio-Cementation, vol. 14, no. 2, pp. 35-39, 2016.

[54] C. Li and Y Gao, "Experimental studies of wind erosion failure of Aeolian soils subgrade for desert highway," Rock and Soil Mechanics, vol. 32, pp. 33-38, 2011, in Chinese.

[55] GB50202-2002, Code for Acceptance of Construction Quality of Building Foundation, Ministry of Construction, Beijing, China, 2002. 